\title{
Effects of Pentazocine on Coronary Hemodynamics under Pentobarbital or Ghloralose-Urethane Anesthesia in Dogs
}

\author{
Tsuneo Yusa, Michio Yoshinari, Toshi Arai and \\ KeNICHI Iwatsuki \\ Department of Anesthesiology, Tohoku University School \\ of Medicine, Sendai
}

\begin{abstract}
Yusa, T., Yoshinari, M., Arai, T. and Iwatscki, K. Effects of Pentazocine on Coronary Hemodynamics under Pentobarbital or Chlaralose-Urethane Anesthesia in Dogs. Tohoku J. exp. Med., 1976, 118 (3), 241-245 — The effect of pentazocine on the coronary hemodynamics was studied in anesthetized dogs. Under pentobarbital anesthesia pentazocine did not cause any significant changes in the coronary hemodynamics. Under chloralose-urethane anesthesia, however, it produced a statistically significant increase in heart rate, left coronary blood flow rate, myocardial oxygen consumption as well as myocardial oxygen extraction rate, but a decrease in coronary vascular resistance. These results indicate that the effects of pentazocine on the coronary hemodynamics are modified significantly by the drugs used for basal anesthesia.__ pentazocine; coronary hemodynamics
\end{abstract}

Pentazocine has been used widely as a non-narcotic analgesic in place of morphine and other narcotics. Recently it has been used also as an alternative for fentanyl in combination with droperidol in neuroleptanalgesia (Iwatsuki et al. 1971). Regarding its circulatory effects pentazocine has been reported to produce an increase in heart rate and arterial blood pressure in conscious men (Keats and Telford 1964; Tammisto et al. 1970; Mostert et al. 1970) and in unanesthetized rabbits (Fogarty et al. 1970). Few reports are available, however, of the effects of pentazocine on the coronary hemodynamics. In the present study the effects of pentazocine on the coronary hemodynamics were studied in anesthetized dogs. Taking into consideration that the drugs used for basal anesthesia may modify the cardiovascular effects of pentazocine, the experiments were carried out in dogs under anesthesia with pentobarbital sodium or chloraloseurethane.

\section{Materials and Methods}

Fourteen healthy mongrel dogs weighing from 9.5 to $14 \mathrm{~kg}$ were used for the experiments. In group 1, 8 dogs were anesthetized with intravenous pentobarbital sodium $(25 \mathrm{mg} / \mathrm{kg})$, and in group 2,6 dogs with intravenous chloralose $(60 \mathrm{mg} / \mathrm{kg})$-urethane $(800 \mathrm{mg} / \mathrm{kg})$. Following endotracheal intubation ventilation was controlled with a volume-

Received for publication, November 10, 1975. 
preset respirator using pure oxygen and end-expiratory $\mathrm{CO}_{2}$ was maintained approximately at $5 \mathrm{vol} \%$ as measured with a infrared $\mathrm{CO}_{2}$ analyzer (Beckman LB-1). Left coronary blood flow rate was determined with a electromagnetic flowmeter (Nihon Kohden MF-2), which was set on a shunt cricuit from the left carotid to the left coronary arteries. Mean aortic blood pressure and cardiac output were measured with an electrical manometer (Nihon Kohden MP-3A) and a dye-densitometer (Erma EN-6), respectively. Heart rate was determined from the electrocardiograms. In some dogs in group 2, contractile force of the left ventricle was measured with a strain gauge arch, and the first time derivatives of left intraventricular pressure (dp/dt) were displayed on a polygraph with other parameters. Arterial and coronary venous blood was drawn for the determination of oxygen content at the same time. Myocardial oxygen consumption and myocardial oxygen extraction rate were calculated from the data obtained.

The measurements were carried out before and $15 \mathrm{~min}$ after the intravenous administration of pentazocine in a dose of $1.5 \mathrm{mg} / \mathrm{kg}$. After the first measurements the drug in the same dose was administered again and similar measurements were repeated. The data were analzyed by Student's t-test.

\section{Results}

The data obtained in both groups are shown in Table 1 and the graphic representations of percent changes in the parameters are shown in Fig. 1. The effects of pentazocine on the coronary hemodynamics in group 1 markedly differed from those in group 2. In group 1 pentazocine in a dose of $1.5 \mathrm{mg} / \mathrm{kg}$ did not cause any significant changes in the parameters. Pentaozcine in the same dose $15 \mathrm{~min}$ afte $r$ the first administration also did not cause any significant changes. On the other hand, in group 2 pentazocine in the same dose produced statistically significant increases in heart rate, left coronary blood flow rate, myocardial oxygen

TABLE 1. Effects of pentazocine on coronary hemodynamics

\begin{tabular}{|c|c|c|c|c|c|c|}
\hline \multirow[b]{2}{*}{$\begin{array}{l}\text { Dose of pentazocine } \\
\text { Time }\end{array}$} & \multicolumn{3}{|c|}{ Group 1 (8 dogs) } & \multicolumn{3}{|c|}{ Group 2 (6 dogs) } \\
\hline & Control & $\begin{array}{l}1.5 \\
15\end{array}$ & $\begin{array}{l}3.0 \\
30\end{array}$ & Control & $\begin{array}{l}1.5 \\
15\end{array}$ & $\begin{array}{l}3.0 \\
30\end{array}$ \\
\hline $\begin{array}{l}\text { Mean aortic blood pressure } \\
\qquad(\mathrm{mmHg})\end{array}$ & $\begin{array}{l}101 \\
\pm 6\end{array}$ & $\begin{array}{r}99 \\
\pm 7\end{array}$ & $\begin{array}{l}85 \\
\pm 7\end{array}$ & $\begin{array}{l}102 \\
\pm 8\end{array}$ & $\begin{array}{l}97 \\
\pm 8\end{array}$ & $\begin{array}{l}88 \\
\pm 7\end{array}$ \\
\hline Heart rate & $\begin{array}{l}158 \\
\pm 7\end{array}$ & $\begin{array}{l}169 \\
\pm 5\end{array}$ & $\begin{array}{l}165 \\
\pm 7\end{array}$ & $\begin{array}{l}128 \\
\pm 10\end{array}$ & $\begin{array}{r}170 \ddagger \\
\pm 7\end{array}$ & $\begin{array}{l}169 \pm \\
\pm 12\end{array}$ \\
\hline Cardiac output & $\begin{array}{l}0.80 \\
\pm 0.03\end{array}$ & $\begin{array}{l}0.99 \\
\pm 0.15\end{array}$ & $\begin{array}{l}0.88 \\
\pm 0.07\end{array}$ & $\begin{array}{l}1.27 \\
\quad \pm 0.27\end{array}$ & $\begin{array}{l}1.31 \\
\pm 0.29\end{array}$ & $\begin{array}{l}1.24 \\
\pm 0.29\end{array}$ \\
\hline $\begin{array}{l}\text { Left coronary blood flow rate } \\
\qquad(\mathrm{ml} / 100 \mathrm{~g} / \mathrm{min})\end{array}$ & $\begin{array}{l}61.0 \\
\pm 3.9\end{array}$ & $\begin{array}{l}60.9 \\
\pm 6.4\end{array}$ & $\begin{array}{l}54.4 \\
\pm 5.9\end{array}$ & $\begin{array}{l}47.4 \\
\pm 2.3\end{array}$ & $\begin{array}{l}63.7^{\dagger} \\
\pm 4.3\end{array}$ & $\begin{array}{l}61.8+ \\
\pm 5.5\end{array}$ \\
\hline $\begin{array}{l}\text { Coronary vascular resistance } \\
(\text { (mmHg/ml/100 } / \mathrm{min})\end{array}$ & $\begin{array}{l}1.83 \\
\pm 0.29\end{array}$ & $\begin{array}{l}1.74 \\
\pm 0.26\end{array}$ & $\begin{array}{l}1.73 \\
\pm 0.30\end{array}$ & $\begin{array}{l}2.32 \\
\pm 0.22\end{array}$ & $\begin{array}{l}1.65^{*} \\
\pm 0.09\end{array}$ & $\begin{array}{l}1.53 \\
\pm 0.13\end{array}$ \\
\hline $\begin{array}{l}\text { Myocardial } \mathrm{O}_{2} \text { consumption } \\
\qquad(\mathrm{ml} / 100 \mathrm{~g} / \mathrm{min})\end{array}$ & $\begin{array}{l}7.9 \\
\pm 0.5\end{array}$ & $\begin{array}{l}8.6 \\
\pm 0.7\end{array}$ & $\begin{array}{l}7.8 \\
\pm 0.5\end{array}$ & $\begin{array}{l}7.4 \\
\pm 0.7\end{array}$ & $\begin{array}{l}9.5 \dagger \\
\pm 1.4\end{array}$ & $\begin{array}{l}9.7 \dagger \\
\pm 1.5\end{array}$ \\
\hline $\begin{array}{r}\text { Myocardial } \mathrm{O}_{2} \text { extraction rate } \\
(\%)\end{array}$ & $\begin{array}{l}81.8 \\
\quad \pm 1.3\end{array}$ & $\begin{array}{l}82.3 \\
\quad \pm 1.7\end{array}$ & $\begin{array}{l}83.0 \\
\pm 2.1\end{array}$ & $\begin{array}{l}67.2 \\
\pm 3.1\end{array}$ & $\begin{array}{l}70.7^{*} \\
\pm 3.3\end{array}$ & $\begin{array}{l}75.2 \dagger \\
\pm 3.7\end{array}$ \\
\hline
\end{tabular}

All values are expressed as mean \pm s.e. and $*(p<.05), \dagger(p<.01), \ddagger(p<.001)$ stand for a statistical signfiicance between the control and the values after pentazocine.

Group 1: Pentobarbital anesthesia. Group 2: Chloraolse-urethane anesthesia. 

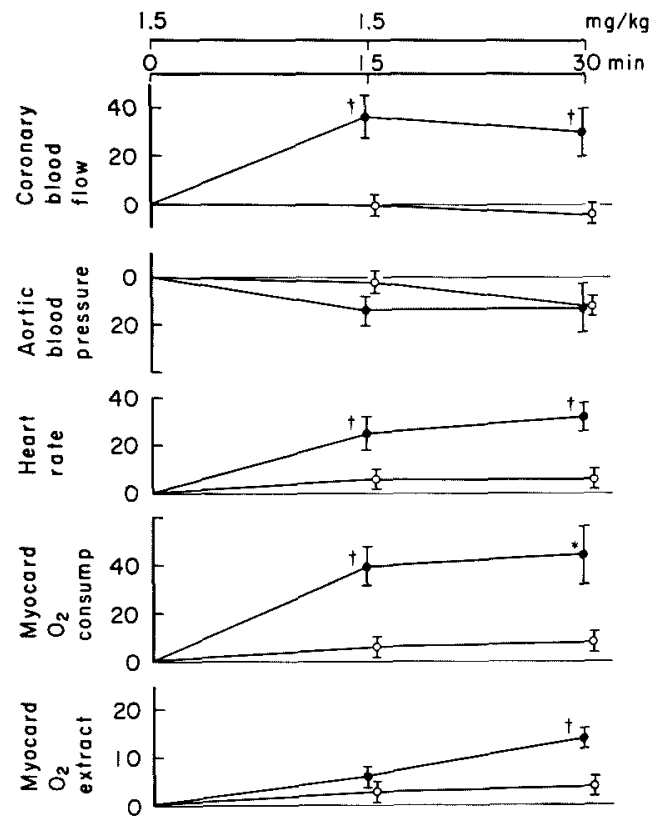

Fig. 1 Percent changes of the parameters of coronary hemodynamics after intravenous pentazocine. Mean values for each point. Vertical bars are \pm s.E. and $*(p<.05)$, $\dagger$ $(p<.01)$ represent a statistical significance between the data in group 1 and those in group 2. $\circ$, Group 1: Pentobarbital anesthesia (8 dogs). ๑, Group 2: Chloraloseurethane anesthesia (6 dogs).

consumption as well as myocardial oxygen extraction rate, but a decrease in coronary vascular resistance. No statistically significant changes were observed in mean aortic blood pressure and cardiac output. The additional administration of pentazocine in the same dose did not increase the changes in these parameters as compared with those after the first administration, except myocardial oxygen extraction rate, which increased with statistical significance after the second administration. Fig. 2 shows one of the typical records in group 2. Left coronary blood flow rate, left ventricular contractile force as well as $\mathrm{dp} / \mathrm{dt}$ of left intraventricular pressure were markedly elevated after pentazocine. Aortic blood pressure also slightly increased following a transient fall immediately after the injection, but $19 \mathrm{~min}$ after the injection it returned to the control level.

\section{Discussion}

In group 1 under pentobarbital anesthesia pentazocine did not cause any significant changes in the coronary hemodynamics. Previously we have reported that a combination of droperidol and pentazocine used in modified neuroleptanalgesia significantly decreased left coronary blood flow rate in dogs anesthetized with pentobarbital sodium (Yusa and Iwatsuki 1974). In view of the results in 


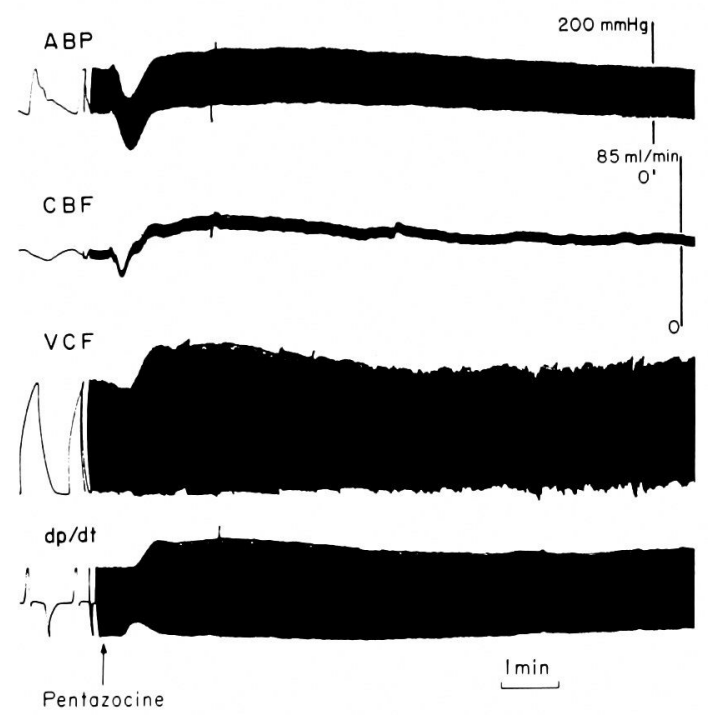

Fig. 2 Changes in aortic blood pressure (ABP), left coronary blood flow rate (CBF), left ventricular contractile force (VCF) and $\mathrm{dp} / \mathrm{dt}$ of left intraventricular pressure after pentazocine $(1.5 \mathrm{mg} / \mathrm{kg})$ in a dog $(12 \mathrm{~kg})$ under chloralose-urethane anesthesia.

the present study, a decrease in coronary blood flow rate under the modified neuroleptanalgesia seemed to be due to the effect by droperidol on coronary blood flow rate.

In group 2 pentazocine caused a significant increase in coronary blood flow rate, myocardial oxygen consumption as well as heart rate. Myocardial oxygen extraction rate was elevated proportionally to the dose of pentazocine. Left ventricular contractile force and $\mathrm{dp} / \mathrm{dt}$ of left intraventricular pressure were also markedly increased after pentazocine. It has been reported that pentazocine produces an increase in heart rate and arterial blood pressure in conscious men (Keats and Telford 1964; Tammisto et al. 1970; Mostert et al. 1970) and in unanesthetized rabbits (Fogarty et al. 1970), but it decreases heart rate and arterial blood pressure in men under nitrous oxide-oxygen anesthesia (Tammisto et al. 1971). These findings suggest that in a conscious state pentazocine may exert a cardiovascular stimulating effect, which is modified by the drugs used for anesthesia. The difference in the results between group 1 and group 2 in the present study seems to be due to the difference of the drugs used for basal anesthesia, suggesting that pentobarbital may mask the stimulating effect of pentazocine.

Pentazocine has been reported to increase plasma catecholamine level, which is coincident with an increase in blood pressure and heart rate (Tammisto et al. 1971). The stimulating action of pentazocine on the cardiovascular system is beneficial to the patient in a hypotensive state, but it may be harmful to the patient with coronary sclerotic heart disease, in whom the augmentation in coronary blood flow rate is restricted. 


\section{References}

1) Fogarty, M., Gill, D., Hill, P. \& Pettit, J. (1970) Cardiovascular effects of pentazocine in rabbits. Brit. J. Pharmacol., 40, 151 .

2) Iwatsuki, K., Suzuki, M., Yusa, T. \& Hashimoto, Y. (1971) Modified neuroleptanestheisa using droperidol and pentazocine. Tohoku. J. exp. Med., 104, 111-120.

3) Keats, A.S. \& Telford, J. (1964) Studies of analgesic drugs. VIII: A narcotic antagonsit. Analgesic without psychomimetic effects. J. Pharmacol. Exp. Ther., 143, 157-167.

4) Mostert, J.W., Evers, J.L., Hobika, G.H., Moore, R.H. \& Murphy, G.P. (1970) Circulatory effects of analgesic and neuroleptic drugs in patients with chronic renal failure undergoing maintenance dialysis. Brit. J. Anaesth. 42, 501-512.

5) Tammisto, T., Jäättelä, A., Nikki, P. \& Takki, S. (1971) Effects of pentazocine and pethidine on plasma catecholamine levels. Ann. Clin. Res., 3, 22-29.

6) Tammisto, T., Takki, S. \& Toikka, P. (1970) A comparison of the circulatory effects in man of the analgesics fentanyl, pentazocine and pethidine, Brit.J. Anaesth., 42, 317-324.

7) Yusa, T. \& Iwatsuki, K. (1974) Effects of modified neuroleptanesthesia on coronary circulation and cardiac mechanical efficiency. Jap. J. Anesth., 23, 869-873. 